\title{
Investigating the role of Electronic Banking Services in improving social welfare (Customers of Melli Bank of Iran in Ahwaz Metropolis)
}

\author{
Hemmat Khodadadi HosseinVand ${ }^{1}$, Idris Mahmoudi ${ }^{2}$
}

${ }^{1}$ MA student of Executive Management in Azad university of Ahwaz.

${ }^{2}$ Faculty Member of Shahid Chamran University of Ahvaz.Email:ed.mahmoodi@scu.ac.ir.

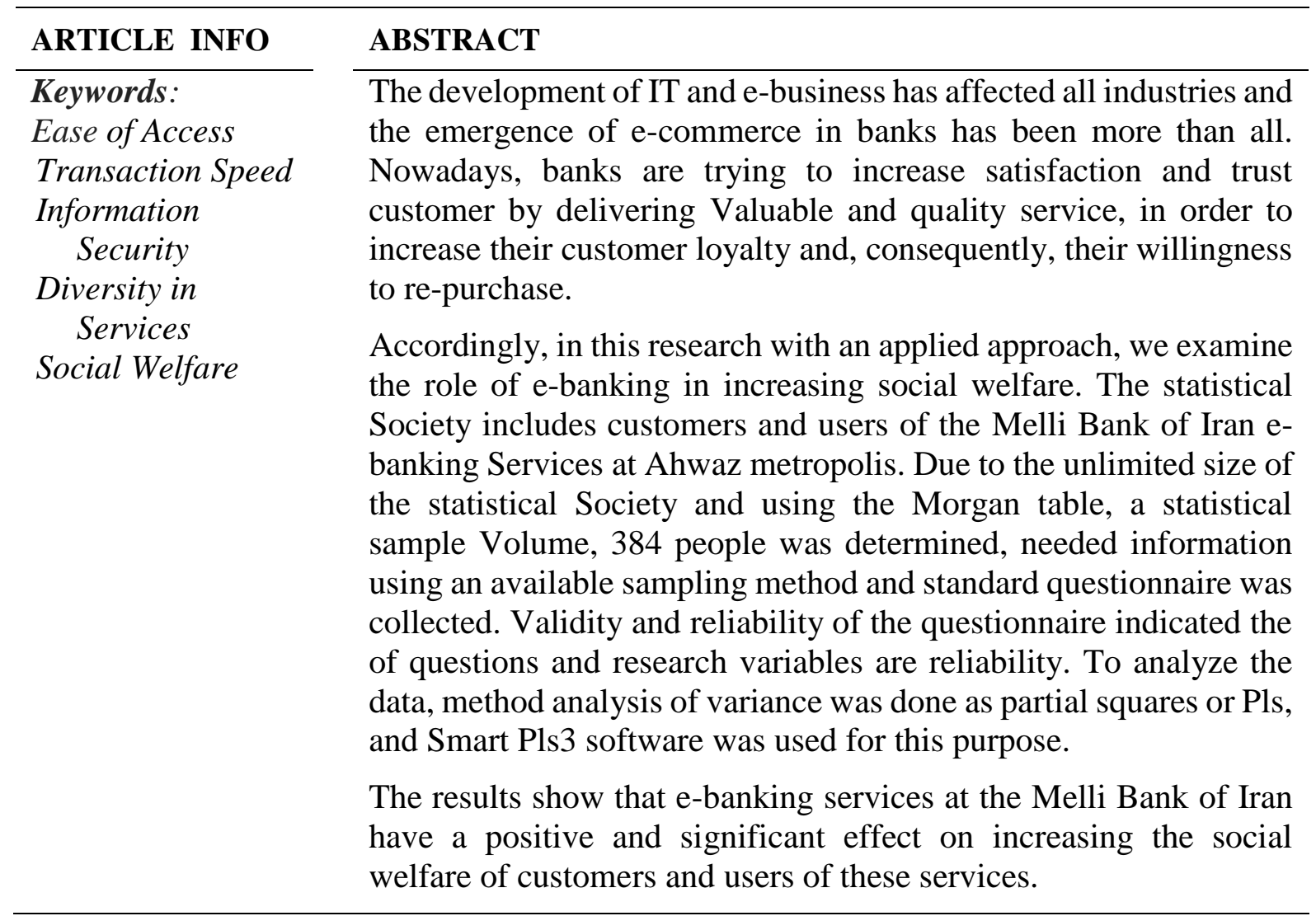

\section{Introduction}

With the development of the electronic systems, geographical distance has lost its meaning and it has led to increase the competition between companies and institutions including banks. Banks should have a competitive advantage in order to achieve the potential market opportunities and overcome the barriers and various threats in the complex business environment. The electronic banking system has provided a background to achieve this advantage. Currently, many of the world's largest banks are providing services and a growing segment of customers who are willing to use their own banking system without referring to branches comes into existence. (ChavoshiRad, 2017)

\section{Definition of Electronic Banking}

Electronic Banking is the creation of facilities to increase the speed and efficiency of the bank in providing banking services at each customer's preferred location and provide hardware and 
software facilities for customers that they can use without the need for physical presence in the bank, 24 hours a day, at any time of the day, through secure and various communication channels to do their bank operations. (Shahrestani, 2014)

Electronic banking is one of the main elements of information technology development in the country and provides easier and cheaper services to the people and reduces the cost of the people and the banking system, as well as improves the quality of banking system services. Electronic Banking is in line with the goals of e-government and one of its most important components; because it has a direct impact on electronic business (Sarfarzie, et al, 2018).

\section{Electronic banking services channels}

Electronic banking is a tool for improving the provision of banking services; therefore, it is presented according to the different needs of customers in methods and various tools such as ATMs, card readers, mobile banks, Internet banking, PayPal, Kiosks Banks and more.

\section{Dimensions and Benefits of Electronic Banking}

Availability, speed, more security and variety of services can be mentioned as dimensions of Electronic Banking. Electronic banking provides many benefits to individuals, such as quick access to the account, the ability to remotely banking transfer and investment and complete electronic applications. With e-banking time and location loses its meaning and serves these services at any time, and it is accessible regardless of where people are located (Rahmani, 2018)

We can refer to the benefits of electronic banking to traditional banking for users as follows:

1) Independency on time and place

2) Easy and quick access to banking services

3) Improving the health and save money by removing the physical money

4) Saving time by speeding up banking affairs

5) Reducing traffic and air pollution by reducing the need to visit the bank

6) Transparency and easy transaction tracking

7) Smart and simple features

8) The possibility of easy and convenient deposit and withdrawal of the salaries of the personnel of the departments and corporations.

9) Easier control and prevention of money laundering

10) Unity of attitude towards the customer

11) and numerous other benefits

\section{Social welfare}

The concept of social welfare has been seriously favored by sociologists, economists and other related majors to development. In fact, since the 1980s many changes have been made in the definition of social welfare. Sociologically and economically related texts show that welfare and well-being which mean to live better; it is not only restricted to vulnerable group of people or a particular group, but also it has wider dimension ( Khodadadi Takhty, 2016).

it is easy to handle complicated administrative tasks by using internet and its capabilities and by electronic banking without the need for going to the bank and doing tasks more quickly and more precisely, they changed the traditional administrative system to the electronic office system. It is obvious that electronic banking will increase the social welfare of bank customers.

\section{The importance and necessity of social welfare}

Since one of the goals of social planning is to achieve social welfare and on the other hand, creating welfare is one of the most important concerns of statesmen in the current world, in short, can be said that in addition to be a human necessity, welfare is an important element in the development of a community. 
Different platforms of development, economics, cultural and... requires to a sense of social welfare. Therefore, there is no doubt about the need to create and maintain prosperity (Safari, 2010).

\section{Social welfare patterns and its different dimensions}

Social welfare has four traditional patterns: the reestablishment of social justice, social development and a new global model. (Also, it includes several dimensions: biological, legal, social, and economic). (khodadadi Takhty, 2016)

Therefore, considering these issues and acknowledging the importance of examining the status of the changing social welfare and the role of electronic banking in creating and promoting it, the main concern in this study is the impact of electronic banking on social welfare of users.

\section{The importance and necessity of the research topic}

Considering the competitive environment created between banks and the use of e-banking services as a means of attracting new customers and increasing customer loyalty, banks need to examine the role of their e-banking services in the social welfare of users of these services, the strengths and weaknesses of the service Identify your e-banking for future decisions and develop these services.

\section{Theories}

First hypothesis: The ease and availability of electronic banking services has a significant effect on the social welfare of customers.

Second hypothesis: The speed of transaction in electronic banking services has a significant effect on the social welfare of customers.

Hypothesis 3: Information security in electronic banking services has a significant effect on the social welfare of customers.

Fourth hypothesis: Diversity in electronic banking services has a significant effect on the social welfare of customers.

Hypothesis 5: Electronic banking services have a significant effect on the social welfare of customers.

\section{Reviewing backgrounds}

Information technology in banks has evolved over the course of four periods, each course has a different degree of work, implies that in every era of information technology development, computers and software have somehow replaced human and paper. These four periods are:

First period: automation of the back counter

Second period: Front account automation

Third period: connecting customers to their accounts

Fourth period: Integrating Systems and Connecting Customers with banking operations (banking website ${ }^{1}$ ).

\section{Electronic Banking in Iran}

In the late 1982s, according to the use of personal computers, banks of the country require to automate computer banking operations. The comprehensive plan of automation banking was approved by the General Assembly of the Bank in 1994. During 1994 and 1995 the idea of creating electronic bank was formed and for this purpose a communication network between Melli bank and citizen's shop was created. In 2000, Iranian Ecommerce Company- IEC was established for creating a payment card system based on the current international model and the establishment of Parsian Bank in 2002 it was sold to Parsian Bank and renamed Parsian Ecommerce Company - PEC. This company has been one of the pioneers of networking payment in the country. In June 2002, a total of regulations governing on the center of the

\footnotetext{
${ }^{1}$ www.banki.ir
} 
network of interbank information exchange called acceleration were approved. Currently, most Iranian banks are directly involved in their e-banking projects (Wikipedia site).

\section{Electronic Banking in the World}

The Internet was developed by academic experts in 1970 to share receipts and its popularity increased for the general public and especially for the business and business men- who was hoping to expand their customers- until 1993. In 1994, banks began to explore the Internet to use the electronic banking as a proactive delivery system for their products and services. Until January 1995, there were only 24 banks on the Internet. But, at a distance of one year, 800 banks were added to this number.

According to a research report by the Data Monitor institute (one of the prominent center of analyzing the banking information in Europe) the statics of users of electronic banking systems in eight countries such as France, Germany, Italy, Netherlands, Spain, Sweden is 4 million people in 1999 reached 22 million in 2004. In 2005, more than 75 percent of active companies in developing countries use one of the electronic banking services.

In the following, we will review the research work carried out on the subject of this or related research in Iran and abroad.

\section{Research background in Iran}

Sohrabi (1396), in a study entitled as the impact of satisfaction of the customers of Electronic banking services and website usability in loyalty of Melli bank customers with the Statistical Society of Western Tehran and by using random sampling method of 200 people conclude that the use of electronic banking services has a positive and significant impact on customer satisfaction.

Khodadadi Takhty (2016) in a study entitled as The Study of the Role of Electronic Banking in Increasing Social Welfare examine the impact of electronic banking services Qarz AlHassaneh Mehr Iran on the welfare of the users of these services and by considering the clients of the Qarz Al- Hassaneh Mehr Iran in branches of Zanjan province as a sample society and by using the random sampling method and statistical sample of 280, results that the establishment of electronic banking in Qarz Al- Hassaneh Mehr Iran has a positive and significant impact on welfare of customers.

Safari Shali et al (2017) they study the degree of feeling of social welfare and its effective factors on studying among citizens of Ardakan city. Independent variables of this research are sense of security, life satisfaction, religiosity, sense of justice, and believing in fate. Descriptive results showed that the level of feeling of social welfare have been evaluated more than three quarters of the respondents at an intermediate level. Inferential findings showed that the effect of the sum of independent variables except for believing in fate on feeling of having social welfare is positive and the total of independent variables might explain $75 \%$ of the variables that change the sense of social welfare.

\section{Research background in abroad}

Foreign research conducted in the field of electronic banking from the beginning of the year to 2005 used qualitative methods and exploratory methods for investigating in electronic banking and its users. But from 2005 to 2010, most of these studies used statistical confirmation methods. AlMuhirat et al (2016) in the study titled Customer Satisfaction from Banking Electronic Banking Services of Saudi Arabia examines the issues of electronic service quality, focusing on information security, ease of use and mechanisms and by selecting a sample of 250 people from customers of Al Rajhi and Al Ahli banks in the Al-Qassim area they realized that Saudi banks have been so successful in obtaining customer satisfaction by improving the characteristics of electronic services. Martin et al (2016) examines this issue in a sample of 110 
people in the statistical society of JCE bank Qana in an investigation entitled the contribution of electronic banking in satisfaction of customer; he concludes that electronic banking brings the performance of banking operations.

Van Quyet et al (2015) in a study on the quality of services and its effects on customer satisfaction in the banking industry with the aim of investigating the relationship between the factors affecting customer satisfaction in the SERVQUAL model in the statistical society of Vietnamese business customers, with a sample of 150 people, conclude that all five factors (tangibility, reliability, accountability, reliability and sympathy with customer have a positive impact on customer satisfaction.

The history of research, except one, is mostly about topics related to the topic of research (and not the subject of research itself) such as studying customer satisfaction and customer loyalty of electronic banking and in the field of research, less has been done. In other words, the subject of this research is a new look at electronic banking.

\section{Research Methodology}

The present research is applied in terms of purpose is functional, since it is at the request of the Melli bank and it leads to executive suggestions to improve the quality of services and customer loyalty; it is also a cross-sectional type in view of time because variables are examined at a time interval from time to time. For data collection and control of variables and in terms of the way of data collection and control of variables are descriptive- correlative. Because it deals with the description of the metafiles without manipulating them and examining the relationship between them.

In this research, the dimensions of electronic banking include ease and access, transaction speed, information security and diversity in services as independent variables, their choice and their impact on social welfare of clients as an associated variable are examined. The conceptual model of research is Figure 1.

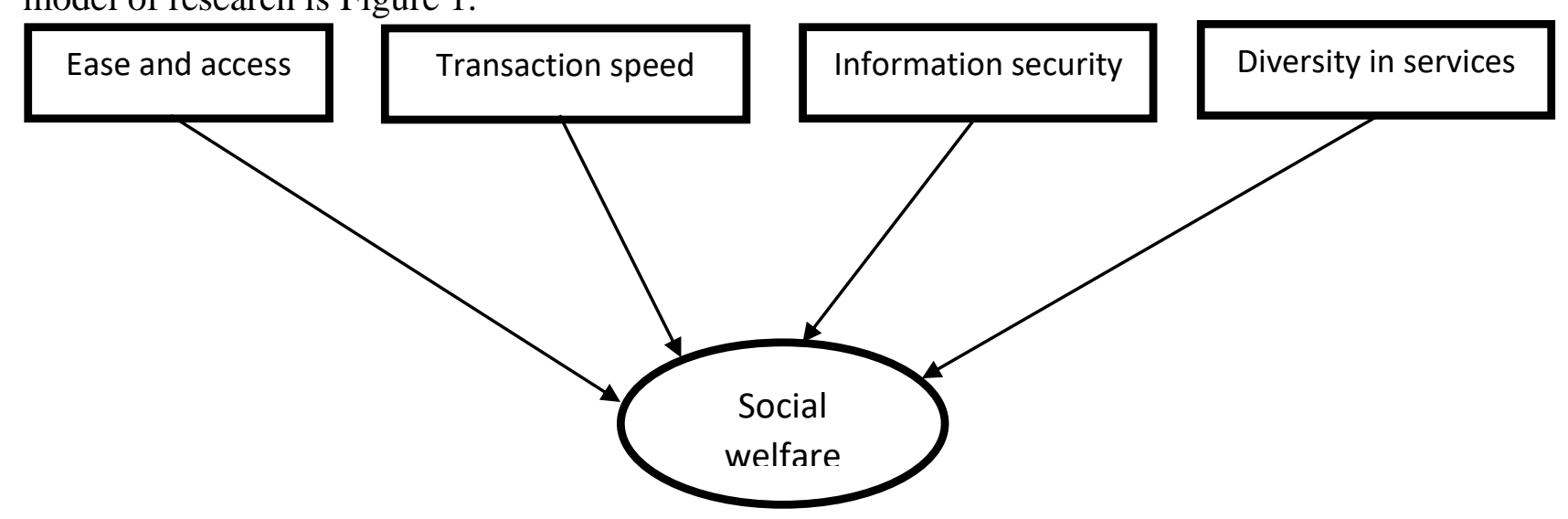

Figure 1: the conceptual model of the research

\section{Society and statistical sample:}

A statistical society is a community made up of individuals or entities that have at least one commonality. Statistical Society of this research includes customers and users of Melli bank's electronic banking services in the metropolitan city of Ahvaz. The sample is a set of elements of a statistical society whose attributes are similar to those of the statistical society and can identify the society and be in harmony with members of society. The statistical sample of this study, using the Morgan table method, and with regard to the unlimited community of this research, is 384 people who are available to be selected. 


\section{Method and tool for data collection}

In order to collect the background and theoretical foundations of the research, the library method and book references, theses, publications, Emerald, Elsevier, Irandoc browsers of Information centers and searching in scientific information databases have been used to achieve the latest achievements of studies and surveys and the completion of Google's search literature such as research and discussion of theoretical issues related to the subject; also, in order to prove the model hypotheses with field studies, at first a preliminary questionnaire was prepared and after determining its validity, the final questionnaire was prepared and the required information was collected.

In the general questions section of the questionnaire, we tried to collect the general and demographic information of respondents that include 3 questions. The specialized questions include 22 questions which we try to design them as simple as possible. To design this section, the 5-degree Likert spectrum has been used.

\section{Data analysis method}

Data analysis is a multi-stage process. Raw data using statistical techniques are analyzed and after processing in form of information are available for users. The data were analyzed by smart PLS and SPSS 19 software and statistical tables at two levels of descriptive statistics and inferential statistics.

In this research, partial least squares analysis is used to test the hypotheses. Partial least squares analysis is a multivariate technique that estimates unobserved variable variables through different indices and a path analysis between these variables. Partial least squares analysis requires no assumption of normal distribution of data and large sample size. Also, in cases where structures are considered by developmental indices, the least partial squares are more appropriate method for data analysis. The reason for using the least squares method in this study is the non-distribution of variables. Two models are tested in the models of PLS. The first model is an external model or a measurement model that examines the validity and reliability of the questionnaire. For this purpose, the alpha and factor load (AVE) for measuring reliability are derived from the Cronbach's mean (CR) extracted variance indices and composite reliability for measuring Convergent validity and the Fornel Larker and transverse load index are used to measure divergent validity. The second model is the internal model or structural model that indicates the relationship between the studied variables. For this purpose, we use the coefficient of determination or $\mathrm{R}^{2}$ and path coefficient or beta. Using the internal model, we can consider the hypothesis of research. And also we will examine the goodness of fit of the research model by the index model of goodness of fit of the GOF.

\section{Data analysis}

Descriptive statistics: Descriptive statistics of the respondents to the questionnaire of this research is in terms of gender, age and education in tables 1.2,3.

Table 1. Distribution of respondents' gender

\begin{tabular}{|c|c|c|}
\hline gender & number & Frequency \\
\hline male & $\mathbf{2 0 5}$ & $\mathbf{6 3 . 5}$ \\
\hline female & $\mathbf{1 1 8}$ & $\mathbf{3 6 . 5}$ \\
\hline total & $\mathbf{3 2 3}$ & $\mathbf{1 0 0}$ \\
\hline
\end{tabular}

Table 2. The distribution of respondent's age

\begin{tabular}{|c|c|c|c|c|c|c|}
\hline Total number & $>50$ & 40 to 50 & 30 to40 & 20 to 30 & $<20$ & Age \\
\hline 325 & 24 & 80 & 123 & 82 & 16 & number \\
\hline 100 & 7.4 & 24.6 & 37.8 & 25.2 & 4.9 & frequency \\
\hline
\end{tabular}


Table 3. Frequency distribution of respondents' education

\begin{tabular}{|c|c|c|c|c|c|}
\hline $\begin{array}{c}\text { Total } \\
\text { number }\end{array}$ & $\begin{array}{c}\text { Master and } \\
\text { doctoral }\end{array}$ & bachelor & associate & $\begin{array}{c}\text { Diploma and } \\
\text { lower }\end{array}$ & education \\
\hline 323 & 52 & 173 & 56 & 42 & number \\
\hline 100 & 16.1 & 53.6 & 17.3 & 13 & frequency \\
\hline
\end{tabular}

\section{Inferential statistics}

- Reliability: in this study, two Cronbach's alpha and composite reliability were used to assess the reliability of the questionnaire.

\section{A. Cronbach's alpha}

One of the most common methods of calculating the validity and reliability of the questionnaire is the calculation of Cronbach's alpha. In figure 2, Cronbach's alpha coefficients are shown.

\section{Construct Reliability and Validity}

\begin{tabular}{|c|c|c|c|c|c|c|c|c|}
\hline \multirow[t]{2}{*}{ Matrix } & 挥章 & Cronbach's Alpha & 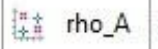 & & Composite Reliability & 㩲真 Average Varia & e Extracted (AVE) & \\
\hline & \multicolumn{4}{|c|}{ Cronbach's Alpha } & rho_A & Composite Reliability & \multicolumn{2}{|c|}{ Average Variance Extracted (AVE) } \\
\hline \multicolumn{3}{|c|}{ Information security } & $\cdot, \wedge \xi 1$ & & $\cdot, \wedge 90$ & $\cdot, 9+9$ & & $\cdot, V \cdot V$ \\
\hline \multicolumn{3}{|c|}{ Variety in services } & $\cdot, \wedge \mp \wedge$ & & $\cdot$, NAT & $\cdot, 9+1$ & & $\cdot, \mathrm{V}$ \% \\
\hline \multicolumn{3}{|c|}{ Social welfare } & $\cdot$, AIV & & $\cdot, \wedge 19$ & $\cdot, \wedge 90$ & & $\cdot, \Delta) Q$ \\
\hline \multicolumn{3}{|l|}{ Transaction } & $\cdot, \Lambda T f$ & & $\cdot, \wedge T V$ & $\cdot, 9 \cdots$ & & $\cdot, \mathrm{VQI}$ \\
\hline \multicolumn{3}{|c|}{ Ease and access } & $\cdot, \wedge \wedge \Delta$ & & $\cdot, \wedge T \Delta$ & $\cdot, A V T$ & & $\cdot$, QV9 \\
\hline
\end{tabular}

Figure2. Cronbach's alpha coefficient

B. Composite Reliability: Composite Reliability or CR is the second criterion for evaluating the reliability. This coefficient differs from zero to one and values higher than 0.7 are accepted and values less than 0.6 are undesirable. Results are shown in Table 4.

Table 4. Composition reliability

\begin{tabular}{|c|c|c|c|c|c|}
\hline $\begin{array}{c}\text { Social } \\
\text { welfare }\end{array}$ & $\begin{array}{c}\text { Variety in } \\
\text { services }\end{array}$ & $\begin{array}{c}\text { Information } \\
\text { security }\end{array}$ & $\begin{array}{c}\text { Transaction } \\
\text { speed }\end{array}$ & $\begin{array}{c}\text { Access } \\
\text { and ease }\end{array}$ & \\
\hline 0.865 & 0.908 & 0.906 & 0.900 & 0872 & $\begin{array}{c}\text { Composition } \\
\text { reliability CR }\end{array}$ \\
\hline
\end{tabular}

According to Fig.2 the values of the Cronbach alpha coefficient are more than 0.7 and also according to Table 4 the values of composite reliability coefficients are all more than 0.7 . Therefore, we can say that our questionnaire has a desirable reliability.

\section{Convergent Validity and Divergent Validity}

A. There will be convergent Validity when scores or scores derived from two or more tools about one concept has a significant correlation. In this study we use two factors of load coefficient and extracted mean variance for evaluating convergent validity.

1) Factor load coefficients: Factor load coefficients are our first indicator for converging validity. After performing a partial least squares test, the numbers that are inserted on the interface lines between questions numbers and variables are load factors. The load factor shows the contribution and role of each question in the formation and explanation of its related variables. Factor load greater than 0.4 is acceptable 


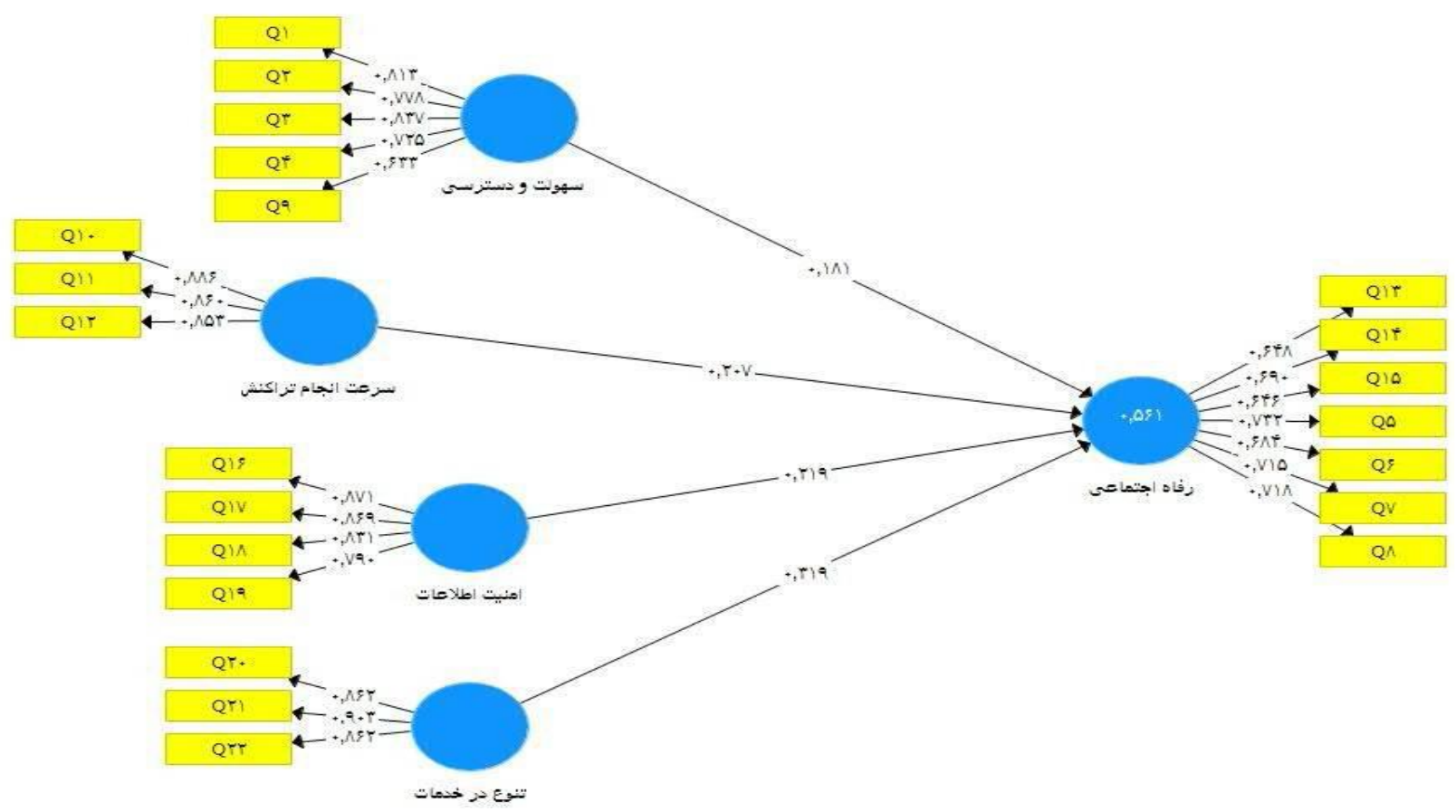

Figure3. Load factor coefficients

As shown in Fig. 3, the factor load coefficients of all questions in this study are greater than 0.4. Therefore, all questions are acceptable and they have been able to explain their own variables.

2) Average variance extracted (AVE) is the second factor to evaluate the convergent validity and this correlation index shows the indices of a structure in comparison with the correlation of the indices of other structures. The value of this coefficient is also zero to one and values greater than 0.5 are accepted and the condition of validity is convergent. As shown in Table 5, the values of this coefficient are all greater than 0.5 . So the values are accepted.

Table 5. Average variance extracted

\begin{tabular}{|c|c|c|c|c|c|}
\hline $\begin{array}{c}\text { Social } \\
\text { welfare }\end{array}$ & $\begin{array}{c}\text { Variety in } \\
\text { services }\end{array}$ & $\begin{array}{c}\text { Information } \\
\text { security }\end{array}$ & $\begin{array}{c}\text { Transaction } \\
\text { speed }\end{array}$ & $\begin{array}{c}\text { Ease and } \\
\text { access }\end{array}$ & \\
\hline 0.515 & 0.767 & 0.707 & 0.751 & 0.579 & $\begin{array}{c}\text { Average } \\
\text { variance }\end{array}$ \\
\hline
\end{tabular}

Considering the values of the factor load coefficients in Fig. 3 and the mean values of the extracted variance in Table 5, it can be said that our questionnaire has a convergent validity desirable.

B) Divergent Validity: A divergent narrative points to this that we need to reduce the correlation between variables that are not assumed to be in the model for each other. If this correlation is low, we can say that the model has a divergent validity. We use the Farnell Larcker and cross loadings in order to show a divergent validity.

1) Fornell larcker: Fornell Larcker criterian is made up of a matrix which is the original diameter in smart pls3 equal to squared value of AVE and in order to prove the reliability of the research model, the values on the original diameter of the matrix should be greater than all of the values in the corresponding column. The results are shown in Table 6. 
Table 6. Fornell Larcker matrix

\begin{tabular}{|c|c|c|c|c|c|}
\hline & $\begin{array}{c}\text { Information } \\
\text { security }\end{array}$ & $\begin{array}{c}\text { Variety of } \\
\text { services }\end{array}$ & $\begin{array}{c}\text { Social } \\
\text { welfare }\end{array}$ & $\begin{array}{c}\text { Transaction } \\
\text { speed }\end{array}$ & $\begin{array}{c}\text { Ease } \\
\text { and } \\
\text { access }\end{array}$ \\
\hline Information security & 0.841 & & & & \\
\hline Variety of services & 0.593 & 0.876 & & & \\
\hline Social welfare & 0.607 & 0.644 & 0.691 & & \\
\hline Transaction speed & 0.484 & 0.490 & 0.570 & 0.866 & \\
\hline Ease and acess & 0.543 & 0.518 & 0.580 & 0.553 & 0.761 \\
\hline
\end{tabular}

2) Cross loadings: cross loading index examines the divergent validity at the modifier level. In this test the load of each modifier for each variable is more than cross loadings. Given the values of the Fornell Larcker coefficients in table 6 and the cross loading, we can say that divergent validity is desirable.

\section{Structural Model or internal Model}

An internal model (structural model) describes the relationships between hidden variables and it specifies how much of the variance of a hidden variable is explained by other hidden variables. To evaluate the model, regular indexes are used for test that includes determination coefficient or $\mathrm{R}^{2}$, path coefficients or Beta coefficients.

4.2.3.1. Path coefficients or Beta coefficients: after executing the test, the least squares numbers that are inserted on hypothesis lines are path coefficients. Path coefficient indicates the severity of the impact and the effect of the research variables on each other and is between -1 to +1 . If it is -1 to zero, the direction is negative. The negative direction between two variables means that these two have inverse relationship and if one increase or decrease, the other one will either increase or decrease and if it is from zero to +1 , the direction is positive; positive direction means that the two variables have direct relationship and if one decrease or increase, the other one will either increase or decrease.

As it has been shown in table 7, the path coefficients of all variables are positive; thus the variables have direct relationship.

Table 7. Path coefficient or Beta coefficient

\begin{tabular}{|l|l|l|}
\hline Independent variables & Dependent variables & Path coefficient \\
\hline Ease and access & \multirow{5}{*}{ Social welfare } & +0.181 \\
\cline { 1 - 1 } Transaction speed & & +0.207 \\
\cline { 1 - 1 } Information security & & +0.219 \\
\cline { 1 - 1 } Service variety & & +0.319 \\
\hline
\end{tabular}

The coefficient of determination or $\mathrm{R}^{\mathbf{2}}$ : After performing the least squares test, as we can see Fig3. Numbers are inserted on the model circles which are called the coefficient of determination or $\mathrm{R}^{2}$. Coefficient of determination indicates the extent to which the dependent variable is influenced by the independent variables. The coefficients of determination of the dependent variables of research are shown in Table 8.

Table 8. Coefficient of determination

\begin{tabular}{|c|c|c|}
\hline Social welfare & R Square & R Square Sdjusted \\
\hline Social welfare & 0.561 & 0.556 \\
\hline
\end{tabular}


The value of this coefficient is from zero to one, and the values close to 67.0 are desirable, nearly 33.0 are normal and close to 19.0 are poorly evaluated.

\section{The goodness of fit index}

The Gof criterion is used to general fit of model in analyzing Smart pls. this numerical index between zero to one and values more than 0.35 indicate the validity of the model. Gof index for the model of this research can be calculated according to the obtained values for AVE and $\mathrm{R}^{2}$ and by using calculated formula of Gof.

$$
\begin{aligned}
\overline{A V E}=\frac{\mathrm{AVE} 1+\mathrm{AVE} 2+\mathrm{AVE} 3+\mathrm{AVE} 4+\mathrm{AVE} 5}{5} \\
=\frac{0.579+0.751+0.707+0.767+0.515}{5}=0.6638
\end{aligned}
$$

$$
\bar{R}^{2}=R^{2}=0.561
$$

$$
\mathrm{Gof}=\sqrt{\overline{\mathrm{AVE}} * \overline{\mathrm{R}}^{2}}=\sqrt{0.6638 * 0.561}=0.61
$$

\section{Testing the significance of coefficients:}

In order to obtain the significance of coefficients or the same coefficients the Hypotheses on the model drawn in the previous stage, we should execute the bootstrapping. The results are shown in figure 4.

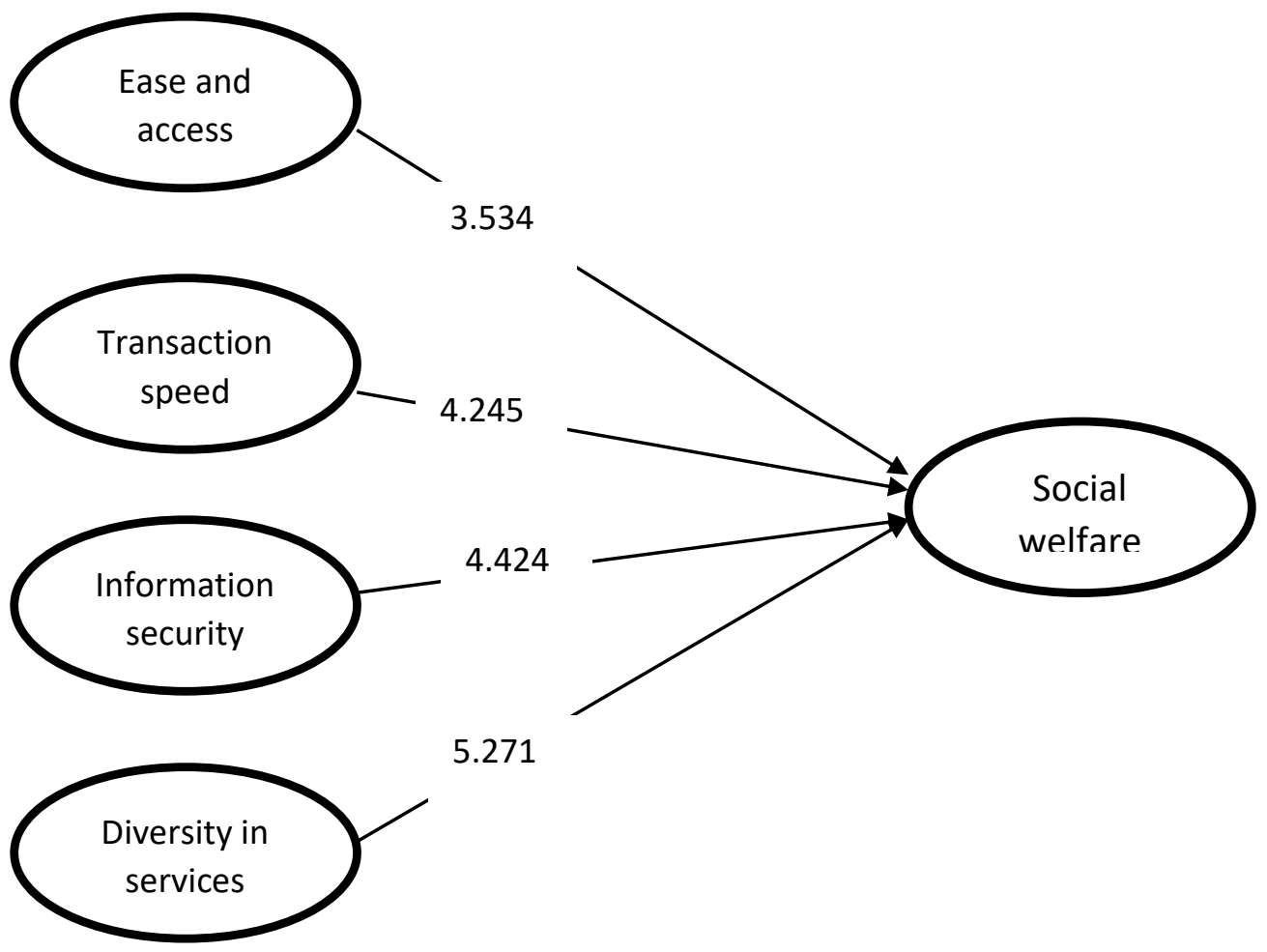

Figure 4. Research model with path coefficients

The significance coefficient of the hypotheses: After applying the above test on the model, numbers are inserted on the lines of the hypotheses that are called the coefficient of significance 
of hypotheses or t coefficient and they show rejection or confirmation of hypothesis. If the value is greater than -1.96 and less than +1.96 , the hypothesis will be rejected and if it is outside of this range, the research hypothesis will be verified.

\section{Reviewing the research hypothesis}

As it can be shown in table 9, the coefficient t of all variables has been shown. By these numbers we can examine the rejection or confirmation of the hypotheses.

Table 9. Coefficients of $\mathrm{t}$ variables

\begin{tabular}{|c|c|c|c|c|}
\hline & $\begin{array}{c}\text { Transaction } \\
\text { speed }\end{array}$ & $\begin{array}{c}\text { Information } \\
\text { security }\end{array}$ & $\begin{array}{c}\text { Diversity in } \\
\text { services }\end{array}$ & Social welfare \\
\hline T coefficient & 3.534 & 4.245 & 4.424 & 5.271 \\
\hline
\end{tabular}

According to table number 9 all of the hypotheses are outside of the -1.96 to +1.96 . therefore, it can be concluded that all hypotheses are confirmed with a 95\% confidence level and, given that their path coefficients were also positive, the relationship between the hypothesis variables is also direct. Therefore, we can say that:

1. The ease and availability of electronic banking services has a positive and meaningful effect on social welfare users of these services.

2. The speed of transaction in electronic banking services has a positive and meaningful effect on social welfare users of these services.

3. Security of information in electronic banking services has a positive and meaningful effect on social welfare users of these services.

4. The diversity of services in electronic banking services has a positive and meaningful effect on the social welfare of users of these services.

Given that all of our sub-assumptions are confirmed with a $95 \%$ confidence level, we can conclude that our main hypothesis has also been confirmed with a 95\% confidence level. Therefore, we can say that electronic banking services have a positive effect and have a significant influence on the social welfare of users of these services.

\section{Discussion and Conclusion}

In response to questions, in almost all cases, men have scored a higher score than women, except in response to question 13 and 14 that the average score of the women's response is higher than men. Given that these two questions relate to the unity of attitude of variables to customer, social justice and equality of opportunities, it can be concluded that banks by providing electronic banking services could take an important step in social welfare and equality between men and women, and it is evident that when women participate meaningfully in all areas of life, they will be able to play a central role in social transformation to create a world of peace, justice and equality.

The answers to questions were categorized and compared to each other in terms of their level of education and there is no significant difference in the average of scores; therefore, it can be said that electronic banking services has been able to have the same effect on increasing social welfare among people with different educational levels.

The component of service diversity has the greatest impact on customer social welfare and users of electronic banking and even higher than important and avoidable component such as information security which proves the fact that the presentation, expansion and diversification in electronic banking services are more than just a kind of incentive and incentive service to attract customers and obtain satisfaction and loyalty, is a basic need for facilitating banking, both for the customer and for the bank. 
Using electronic technology to carry out banking affairs is one of the most important achievements of the advancement of science and technology and their use for human wellbeing and comfort. Electronic banking uses features such as speed, availability, security, diversity in the provision of services has made it easy and convenient to do banking, reduce traffic and air pollution, cost and time saving, social justice and equality of opportunity, security, diversity of needs and desires of bank customers and, in general, creating social welfare in the mental and material dimension. Also, due to its extensibility and high flexibility of electronic banking, there is an appropriate field for more and better use in the banks for providing services through electronic banking; it can be said that electronic banking services are one of the requirements in facilitating customer banking and a useful and powerful tool for managers of banks to implement the short term and long term programs of bank.

\section{References}

Al-Muhirat.A\&Hani.A(2016). Customer Satisfaction with Electronic Banking Services in the Saudi Banking Sector,Asian Social Science,No. 5,pp.139-146,2016.

Chavoshid Rad. L \&Chavoshid Rad.R\&Rezaei Manesh.A (2016). Evaluation of Perceptual Services Quality in Customer Satisfaction with Internet Services of Parsian Bank in Tehran Branch Branch, Fourth National Management Conference, Economics and Accounting, Tehran, 2016

Khodadadi Takhty. Y (2016). The Role of Electronic Banking on Social Welfare, Third International Conference on Applied Research in Management and Accounting. Tehran, 2016

Martin.O\&Kwaku.N,G(2016). The contribution of electronic banking to customer satisfaction,International Journal of Managing Information Technology (IJMIT),No.1,pp.1$11,2016$.

Rahmani.M (2017). Investigating the Factors Affecting the Reception of Electronic Banking, The 10th Management and Economics Conference, Tehran, 2017

Safari.R(2012). Social Affect and its Effective Factors on the Case of Tehran, Journal of Urban Planning Research, Vol. 5, pp. 1-22, 2012

Safari Shali.R\& Mehdizadeh Ardakani.M (2016). Assessing the level of social welfare and its effective factors, Journal of Welfare and Social Development Planning, No. 30, pp. 177224,2016

Sarfarazi. M\& Yahiaee. M\& Fouladi. H (2017) The Need for Electronic Banking and the Study of its Progress in Iran, International Conference on Challenges and Strategies for Economic Development and Management, UAE-Dubai, 2017

Shahrestani.M (2013). Impact of Electronic Banking Efforts to Increase Satisfaction of Bank Customers, Master's Thesis, Iran University of Science and Technology, 2013

Sohrabi.P (2017). The Effect of Satisfaction of Electronic Banking Services and Website Usability in Customer Loyalty of the National Bank, National Management Conference, Tehran, 2017

Van Quyet.T\&Quang Vinh.N\&Chang.T(2015). Service Quality and Its Effects on Customer Satisfaction with Deposit Services in the Banking Industry, Advanced Science and Technology Letters, no.102, pp.18-23,2015. 